\title{
Genetic Relationship Based on RAPD Analysis of Yeosu Dolsan Leaf Mustard (Brassica juncea)
}

\author{
In-Ho Lee, Jong-In Park, Oon-Sup Jeong', Hyo-Jin Jung², Gun-Ho Jung ${ }^{3}$ and III Sup Nou* \\ Department of Horticulture, Sunchon National Univ., Sunchon 540-742, Korea \\ ${ }^{1}$ Division of Special Prouct Promotion, Yeosu-si Agriculttural Technology \& Extension Center, Yeosu 555-130, Korea \\ ${ }^{2}$ Department of Horticulture, Jeollanam-do Agricultural Research and Extension Services, Jeollanam-do 520-715, Korea
}

Received October 21, 2009 / Accepted December 26, 2009

\begin{abstract}
The genetic relationships of 14 Dolsan leaf mustard (Brassica juncea) lines were analysed using random amplified polymorphic DNA (RAPD) analysis. Thirty nine random primers were tested and seven primers which showed polymorphism were selected. The amplified fragments ranged from 0.2 to $3.5 \mathrm{~kb}$ in size. The number of bands amplified in each primer showed the variations ranging from 2 to 27, with an average of 8.7. Based on the UPGMA cluster analysis, 14 lines were separated into three groups. The results showed that RAPD analysis was useful in the genetic diversity and in the cross combination of the $\mathrm{F}_{1}$ hybrid of leaf mustard.
\end{abstract}

Key words : Brassica juncea, RAPD, polymorphism

\section{서 론}

갓(Brassica juncea)은 십자화과(Cruciferae)에 속하는 일년 생 초본이며, 엽경 채소류 중의 하나로 중국이 원산지이나 현 재는 한국과 일본 등에서 널리 재배되고 있다[5]. 특히 우리나 라에서 전라남도 여수 돌산지역을 중심으로 재배되고 있는 ‘돌산 갓'은 일본 고채품종인 '만생평경대엽고채'와 ‘청경대엽 고채'가 해방 이후 돌산 읍 세구지 마을에 도입되어 재배된 것으로 재래 갓(청갓, 적갓)과의 외형적 특성 및 맛의 차이가 뚜렷하고 지역토성에 알맞아 재래시장인 여수 서시장에 출하 됨으로써 '돌산 갓'으로 명명되었고[11], 현재 매운맛이 적으며 특유한 향 등이 우수하여 김치 제조용으로 재배하고 있다[12].

현재 갓 김치용 국내품종들은 종자산업법에 의해 출원 - 설 정등록 보호 관리되고 있는 것은 없고, 여수시가 ‘07 ’08년에 늦동이 등 5 개 품종을 출원하여 심사중인 갓품종이 전부이며 아직 품종보급 체계가 미흡하여 자가채종에 의한 자식약세 현상, 종자의 기계적 혼입 및 방임수분에 의한 순도저하, 상품 의 불균일 등의 문제점이 발생하고 있다. 이러한 문제를 해결 하기 위하여는 $\mathrm{F}_{1}$ 품종 육성체제를 갖추어야 한다. 신품종 육 성을 위해서는 유전자원의 수집과 보전 및 평가가 필수적으로 이루어져야 한다. 따라서 갓의 계통 구분 및 우량계통의 선발 이 요구된다.

작물의 유전적 유연관계를 평가하는 방법으로 과거에는 주 로 작물의 육종기록과 식물의 형태적 특성 및 생화학적 인자 인 동위효소 다형화 분석에 근거를 두어 왔으나, 최근에 생물

\footnotetext{
*Corresponding author

Tel : +82-61-750-3249, Fax : +82-61-750-3208

E-mail : nis@sunchon.ac.kr
}

공학의 발달과 더불어 새로 개발된 RFLP, RAPD, Microsatellites, $\mathrm{AFLP}, \mathrm{STS}, \mathrm{EST}$ 등의 DNA marker들을 이용하여 품종 감별 이나 품종 등록, 계보추적, 유전자형간 유전적근연도 추정, 집 단의 변이정도 평가 등의 연구가 활발히 진행되고 있다[6-8]. 다양한 분자생물학적 방법을 이용한 분석이 다양한 품종의 육성과정에 활용되고 있는데, 이 중 Willams 등[15]에 의하여 개발된 Randomly Amplified Polymorphic DNA (RAPD) 분 석방법이 유연관계 분석에 많이 활용되고 있다[2,7]. RAPD marker를 이용한 분석방법은 비교적 간편하고 그 비용도 상대 적으로 낮아 유전적 다양성과 품종의 finger printing에 효과 적으로 이용되고 있다[3,9,17,18]. 빠른 시간 내에 대규모 집단 의 screening에 효과적인 방법으로 유전적 변이의 감별, 유전 자 지도의 작성 및 모본의 확인 등 그 이용성이 다양하다. 또한 Han 등[4]은 RAPD 분석을 통해 벼의 인디카 품종과 자포니카 품종을 구분할 수 있었다. 다수성 품종육성에서 교배친의 유 전적 다양성은 후대의 분리정도와 형질변이에 매우 중요한 영향을 미친다. 일부 연구자들은 효과적인 교배친의 선정을 위하여 RAPD 방법에 의한 교배친의 유전적 차이와 잡종후대 의 잡종강세간의 관련성을 검토한 바 있는데 Saghai Maroof 등[14]은 벼 인디카와 자포니카간 교잡에서 RAPD 분석에 의 한 교배친의 유전적 차이와 잡종강세는 높은 상관이 있다고 보고하였고, Xiao 등[16]은 인디카 및 자포니카내의 교잡에서 $\mathrm{RAPD}$ 와 SSR를 이용한 유전적 다양성은 수량성 및 잡종강세 와 높은 상관이 있다고 하였다.

본 연구는 여수시농업기술센터에서 여수 돌산 갓 고유품 종 육성을 위해 지난 2001년부터 꾸준한 연구를 통해 돌산지 역 재배포장에서 생태적으로 적응한 갓을 선발하여 분리육 종 기술로 선발된 14 품종의 RAPD분석에 의한 유연관계를 
분석하여 $\mathrm{F}_{1}$ 조합 작성을 위한 원연계통을 선발하고자 수행 하였다.

\section{재료 및 방법}

\section{공시 재료}

여수시농업기술센터에서 분리육종 기술로 선발된 14 품종 의 생육특성 및 형태적 특성을 10 개체씩 3 번에 걸쳐 조사한 후, 잎조직으로부터 DNA를 추출하여 RAPD 분석에 이용하 였다.

\section{Total DNA 추출 및 정제}

DNA 추출은 cetyltrimethyl ammonium bromide (CTAB) 방법[10]을 응용하여 추출하였다. 새로 신장한 어린 잎 $0.2 \mathrm{~g}$ 을 막자사발에 넣고 액체질소로 마쇄하여 extraction buffer 15 $\mathrm{ml}[2 \%$ (w/v) CTAB, $100 \mathrm{mM}$ Tris (pH 8.0), $500 \mathrm{mM} \mathrm{NaCl}$, $50 \mathrm{mM}$ EDTA]와 2-mercaptoethanol $750 \mu \mathrm{l}, 20 \%$ SDS $1 \mathrm{ml}$ 을 첨가한 후 $65^{\circ} \mathrm{C}$ 에서 10 분간 반응시켰다. $5 \mathrm{M}$ potassium acetate $5 \mathrm{ml}$ 를 첨가한 후 얼음에 20 분간 방치한 후 $4^{\circ} \mathrm{C}, 15,000$ $\mathrm{rpm}$ 에서 10 분간 원심분리 하였다. 상층액을 새로운 튜브에 옮긴 후 isoprophanol를 $10 \mathrm{ml}$ 첨가하고 $-20^{\circ} \mathrm{C}$ 에 20 분간 방치 하였다. 튜브를 꺼내 다시 원심 분리시킨 다음 상등 액을 버리 고 건조시킨 후 $1 \times \mathrm{TE}$ buffer $500 \mu \mathrm{l}$ 에 녹였다. 동량의 phenol 과 chloroform을 첨가하여 DNA를 정제하였고 isoprophanol $500 \mu \mathrm{l}$ 와 $3 \mathrm{M}$ sodium acetate $75 \mu \mathrm{l}$ 를 넣고 원심 분리시켜 $\mathrm{DNA}$ 를 침전시켰다. $100 \mu \mathrm{l}$ 의 $1 \times \mathrm{TE}$ buffer로 $\mathrm{DNA}$ 를 용해시 켰으며, spectrophotometer (Optizen 3220UV)를 이용하여 $\mathrm{DNA}$ 를 정량하였다. 이 $\mathrm{DNA}$ 를 $\mathrm{PCR}$ 분석의 template로 사용 하였다.

\section{$\mathrm{RAPD}$ 및 유연관계 분석}

RAPD 분석을 위해 Perkin-Elmer사의 PE-9700을 이용하여 PCR 반응을 수행하였으며, PCR 반응액은 template DNA 10 ng, 50 pmol random primer, 10× Ex buffer, dNTP, 1 U Ex $\operatorname{Taq}$ (TaKaRa, Japan)를 혼합하여 최종량을 $25 \mu \mathrm{l}$ 로 하였다. Random primer는 시판되는 39종(OPA 20종, OPB 19종, Operon Co, USA)을 사용하였다(Table 2). PCR 증폭 반응은 $94^{\circ} \mathrm{C}$ 에서 5 분간 pre-denaturation한 다음 $94^{\circ} \mathrm{C}$ 에서 30 초간 denaturation, $39^{\circ} \mathrm{C}$ 에서 1 분간 annealing, $72^{\circ} \mathrm{C}$ 에서 1 분간 extension을 45 회 반복한 후, $72^{\circ} \mathrm{C}$ 에서 10 분간 post-extension하 였다. 증폭된 PCR 산물은 $1.5 \%$ agarose gel에 전기영동한 후 $\mathrm{UV}$ transilluminator를 이용하여 증폭된 DNA 단편을 확인하 였다. 실험의 재현성을 위해 2회 반복 실험하여 증폭된 DNA 단편을 확인하였다. RAPD 분석결과 다형성을 나타내는 DNA 단편의 유무에 의해있는 경우는 1 , 없는 경우는 0 으로 기록하 고 기초 행렬을 작성하였다. 유연관계 분석은 $\mathrm{Nei}$ 와 $\mathrm{Li}$ [11]의 방법에 준하여 유사도 지수를 계산한 후 작성된 정보를 통계 프로그램인 NTSYS complete Program (Numerical taxonomy system과 multivariate analysis system, version 2.1, Applied Biostatistics Inc, USA)을 이용하여 유사도 값을 구했으며, UPGMA clustering 방법으로 14 품종간의 유연관계를 분석하 였다.

\section{결과 및 고찰}

김치 제조용 돌산 갓으로 육성된 14 품종의 일반적인 특징 8 개의 형질 값을 Table 1에 나타내었다. 14 품종들은 각 형질들 에 있어서 다양한 변이를 보였다. 엽장은 최고 $38.5 \mathrm{~cm}$, 최소 $27 \mathrm{~cm}$ 를 나타내었고, 엽수는 7 13 장의 잎을 가지고 있었다.

Table 1. Morphological characteristics of used 14 leaf mustard

\begin{tabular}{|c|c|c|c|c|c|c|c|c|}
\hline Lines & $\begin{array}{l}\text { Leaf length } \\
(\mathrm{cm})\end{array}$ & $\begin{array}{l}\text { Number } \\
\text { of leaf (ea) }\end{array}$ & $\begin{array}{c}\text { Leaf diameter } \\
(\mathrm{cm})\end{array}$ & Leaf type & $\begin{array}{c}\text { Phylloplane } \\
\text { hair }\end{array}$ & Leaf curl & Anthocyanin & Bolting \\
\hline JA-1 & $31.5 \pm 0.7^{z}$ & $9.0 \pm 1.0$ & $18.0 \pm 0.4$ & Radish & nothing & minim & nothing & early $(4 / 1)^{y}$ \\
\hline JB-1 & $31.5 \pm 0.3$ & $7.7 \pm 0.6$ & $19.0 \pm 0.2$ & Chinese cabbage & nothing & minimum & nothing & normality $(4 / 11)$ \\
\hline JC-1 & $32.5 \pm 0.1$ & $11.3 \pm 0.6$ & $19.5 \pm 0.0$ & Chinese cabbage & nothing & middle & nothing & early $(4 / 1)$ \\
\hline JC-4 & $32.0 \pm 0.4$ & $14.0 \pm 1.0$ & $15.5 \pm 0.7$ & Radish & existence & no & nothing & early $(4 / 1)$ \\
\hline JD-2 & $29.5 \pm 0.1$ & $8.0 \pm 1.0$ & $16.5 \pm 0.2$ & Radish & existence & no & nothing & very late autumn $(5 / 2)$ \\
\hline $\mathrm{JA}-4$ & $31.0 \pm 0.3$ & $14.0 \pm 1.0$ & $19.0 \pm 0.2$ & Chinese cabbage & nothing & minimum & nothing & normality $(4 / 11)$ \\
\hline JA-2 & $37.0 \pm 0.1$ & $11.3 \pm 1.5$ & $16.3 \pm 0.1$ & Radish & nothing & minimum & nothing & early $(4 / 1)$ \\
\hline JB-2 & $33.5 \pm 0.4$ & $9.3 \pm 1.5$ & $19.0 \pm 0.3$ & Chinese cabbage & nothing & no & nothing & early $(4 / 1)$ \\
\hline $\mathrm{JC}-2$ & $36.0 \pm 0.3$ & $13.0 \pm 1.0$ & $15.5 \pm 0.2$ & Radish & existence & no & nothing & early $(4 / 1)$ \\
\hline JC-3 & $38.5 \pm 0.4$ & $13.3 \pm 1.0$ & $18.3 \pm 0.3$ & Radish & existence & no & nothing & early $(4 / 1)$ \\
\hline JE-1 & $32.5 \pm 0.1$ & $14.3 \pm 1.5$ & $18.5 \pm 0.2$ & mixture & nothing & minimum & nothing & normality $(4 / 6)$ \\
\hline JC-4 & $32.0 \pm 0.0$ & $8.0 \pm 1.0$ & $17.5 \pm 0.0$ & Radish & nothing & middle & nothing & late autumn $(4 / 21)$ \\
\hline JD-4 & $27.0 \pm 0.4$ & $9.3 \pm 1.2$ & $15.5 \pm 0.4$ & Radish & nothing & no & minimum & late autumn $(4 / 25)$ \\
\hline JC-5 & $38.5 \pm 0.1$ & $13 \pm 1.0$ & $18.3 \pm 0.1$ & Radish & existence & no & nothing & early $(4 / 1)$ \\
\hline
\end{tabular}

\footnotetext{
${ }^{\mathrm{z}}$ mean \pm standard deviation. ${ }^{\mathrm{y}}$ bolting date.
} 
엽폭은 최대폭 $19.5 \mathrm{~cm}$, 최소폭 $15.5 \mathrm{~cm}$ 를 나타내었다. 엽형은 3 그룹으로 나뉘어 졌는데 표현형으로는 무엽형이 9 품종 (JA-1, JC-4, JD-2, JA-2, JC-2, JC-3, JC-5, JD-4, JC-6), 배추 형이 4 품종(JB-1, JC-1, JA-4, JB-2), 중간형이 1 품종(JE-1)로 조사되 었다. 옆에 털이 있는 갓 품종은 JC-4, JD-2, JC-2, JC-3, JC-5 이었다. 추대성 조사에서도 보통, 만추, 극만추의 3 개의 그룹 으로 나뉘어 졌는데 JC-5와 JD-4품종이 만추성을 나타내었고, JD-2품종은 극만추성을 나타내었다(Table 1). JD-2품종의 주요 특성으로서는 i) 식물체는 중간형이며 자엽이 크고 배축의 안 토시아닌이 없거나 매우 약하였으며 ii) 엽색은 연록색이며 표 면의 물결이 약하면서 잎 수가 작고 털의 수와 엽장은 중간정 도, 결각의 크기가 작으며 도란형을 나타내었고 iii) 중륵은 반 원형으로 폭과 두께가 중간, 중륵과 엽병에 혹·꼬임이 없었으 며 iv) 엽병의 길이가 짧고 추대에 있어서 조기추대품종보다 온도와 일장에 아주 둔감하여 추대성이 30 일이 늦은 극만추성 및 비결구성을 나타내었다. 따라서 이러한 특징을 나타내는 $\mathrm{JD}-2$ 품종은 추대가 일찍 되어 수량이 떨어지지만 가격이 가장 높게 형성되는 시기로 판로 걱정이 없어 소득을 높일 수 있는 여름철 단경기 재배종으로 유리한 품종으로 판단되었다.

작물의 유전적 유연관계 분석 및 다양성 분석 방법으로 과 거에는 주로 작물의 육종기록과 식물의 형태적 특성 및 생화 학적 인자인 동위효소 다형화 분석에 근거를 두어 왔으나, 최 근에 다양한 분자생물학적 방법을 이용한 분석이 다양한 품종 의 육성과정에 활용되고 있는데[6-8], 이 중 Willams 등[15]에 의하여 개발된 RAPD 분석방법이 경제적 잇점으로 인하여 유 연관계 분석에 많이 활용되고 있으므로[2,7], 순계로 분리한 14 품종으로 부터 total DNA를 추출, 정제하여 RAPD 분석법 을 이용하여 이들 품종들 간의 유연관계를 분석하였다. 시판 의 random primer 39종(Operon Co, USA)을 사용하여 PCR을 수행하였으며, oligonucleotide의 염기서열과 $\mathrm{G}+\mathrm{C}$ 함량은 Table 2에 나타냈다. 각각의 primer에 있어서 $1.5 \%$ agarose gel상에서 분획한 DNA 단편 수는 2 개에서 27 개로 다양하게 나타내었다. PCR 증폭된 DNA 단편의 크기는 $0.2 \mathrm{~kb}$ 에서 3.5 $\mathrm{kb}$ 의 범위에 위치하였으며, 평균 8.7 개의 단편이 증폭되었다 (Table 2). 본 실험에 사용된 random primer 39종은 모두 10 mer로써 기존에 보고된 갓[12], 순무[1]에서의 평균 단편수와 유사하였지만, 브로콜리[13]의 3.7개 보다는 평균 단편수가 많 았다.

39종의 Random primer에서 특이적 band로 검출 된 24종 의 primer를 찾을 수 있었다(Table 2). PCR 증폭 단편의 다형 성과 재현성이 확실하면서 단편의 구분이 뚜렷한 OPA-4, OPA-7, OPA-8, OPA-11, OPA-14, OPB-6, OPB-18의 7종의 primer를 선발하였고, 이 중 4 종의 primer를 이용하여 증폭한 $\mathrm{PCR}$ 산물을 $1.5 \%$ agarose gel상에 분획한 것을 Fig. 1에 나타 냈다. 24종의 primer로부터 증폭된 52개 DNA 단편을 기초로 순계분리한 14 품종간의 Genetic similarity matrix를 분석하
Table 2. Primer sequences and number of amplified fragments

\begin{tabular}{|c|c|c|c|c|c|}
\hline \multicolumn{2}{|l|}{ Primer } & $\begin{array}{l}\text { Oligonucleotide } \\
\text { sequence } \\
\left(5^{\prime} \text { to } 3^{\prime}\right)\end{array}$ & $\begin{array}{c}\mathrm{G}+\mathrm{C} \\
\text { contents } \\
(\%)\end{array}$ & $\begin{array}{c}\text { No. of } \\
\text { amplified } \\
\text { fragments }\end{array}$ & $\begin{array}{l}\text { Detection } \\
\text { of specific } \\
\text { band }\end{array}$ \\
\hline \multirow{20}{*}{ OPA } & 01 & CAGGCCCTTC & 70 & 6 & 0 \\
\hline & 02 & TGCCGAGCTG & 70 & 5 & O \\
\hline & 03 & AGTCAGCCAC & 60 & 6 & 0 \\
\hline & 04 & AATCGGGCTG & 60 & 7 & 0 \\
\hline & 05 & AGGGGTCTTG & 60 & 10 & 0 \\
\hline & 06 & GGRCCCTGAC & 70 & 8 & - \\
\hline & 07 & TTCCCCCGCT & 70 & 5 & O \\
\hline & 08 & CCACAGCAGT & 60 & 8 & O \\
\hline & 09 & GGGTAACGCC & 70 & 9 & O \\
\hline & 10 & GTGATCGCAG & 60 & 13 & 0 \\
\hline & 11 & CAATCGCCGT & 60 & 9 & 0 \\
\hline & 12 & TCGGCGATAG & 60 & 13 & - \\
\hline & 13 & CAGCACCCAC & 70 & 12 & O \\
\hline & 14 & TCTGTGCTGG & 60 & 4 & 0 \\
\hline & 15 & TTCCGAACCC & 60 & 3 & 0 \\
\hline & 16 & AGCCAGCGAA & 60 & 5 & - \\
\hline & 17 & GACCGCTTGT & 60 & 7 & O \\
\hline & 18 & AGGTGACCGT & 60 & 10 & O \\
\hline & 19 & CAAACGTCGG & 60 & 17 & - \\
\hline & 20 & GTTGCGATCC & 60 & 10 & - \\
\hline \multirow{19}{*}{ OPB } & 01 & GTTTCGCTCC & 60 & 14 & - \\
\hline & 02 & TGATCCCTGG & 60 & 2 & O \\
\hline & 03 & САТСССССТG & 70 & 12 & 0 \\
\hline & 04 & GGACTGGAGT & 60 & 9 & - \\
\hline & 06 & TGCTCTGCCC & 70 & 9 & 0 \\
\hline & 07 & GGTGACGCAG & 70 & 10 & 0 \\
\hline & 09 & GTCCACACGG & 70 & 27 & - \\
\hline & 09 & TGGGGGACTC & 70 & 15 & - \\
\hline & 10 & TGCCGAGCTG & 70 & 5 & 0 \\
\hline & 11 & GTAGACCCGT & 60 & 6 & - \\
\hline & 12 & CCTTGACGCA & 60 & 17 & - \\
\hline & 13 & TTCCCCCGCT & 70 & 4 & - \\
\hline & 14 & TCGGCGATAG & 60 & 3 & O \\
\hline & 15 & GGAGGGTGTT & 60 & 5 & O \\
\hline & 16 & TTTGCCCGGA & 60 & 4 & - \\
\hline & 17 & AGGGAACGAG & 60 & 7 & 0 \\
\hline & 18 & CCACAGCAGT & 60 & 5 & 0 \\
\hline & 19 & ACCCCCGAAG & 70 & 12 & - \\
\hline & 20 & GGACCCTTAC & 70 & 8 & - \\
\hline
\end{tabular}

${ }^{\circ} \mathrm{O}$ : These primers are detected of specific band

-: These primers are not detected of specific band.

기 위하여 PCR 증폭된 밴드의 유, 무에 따라 유는 1 , 무는 0 으 로 데이터화하고 NYSYS Complete Program을 이용하여 유사 도 값을 구했다. 그 결과 돌산 갓 14 품종간의 유사도 계수는 0.49 0.86 사이로 나타났다. 분획된 단편의 종류(크기, 수)를 분석한 결과 14 품종의 돌산 갓은 Coefficient 0.535 를 기준으 로 3개의 그룹으로 구분할 수 있었다. 그룹 I 은 JA-1, JA-2; 


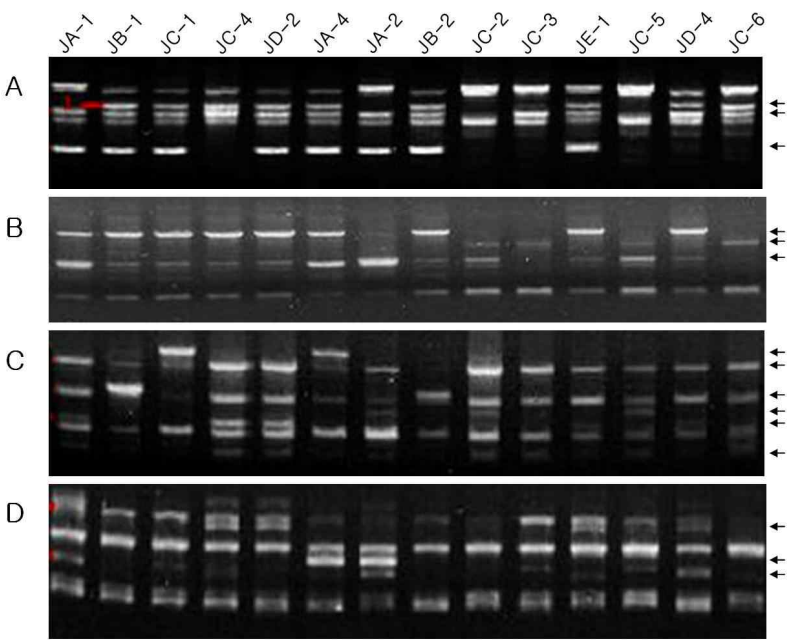

Fig. 1. RAPD polymorphims of 14 accessions using OPA-04(A), OPA-07(B), OPA-11(C), OPB-07(D) primers. The specific bands are indicated by arrows.

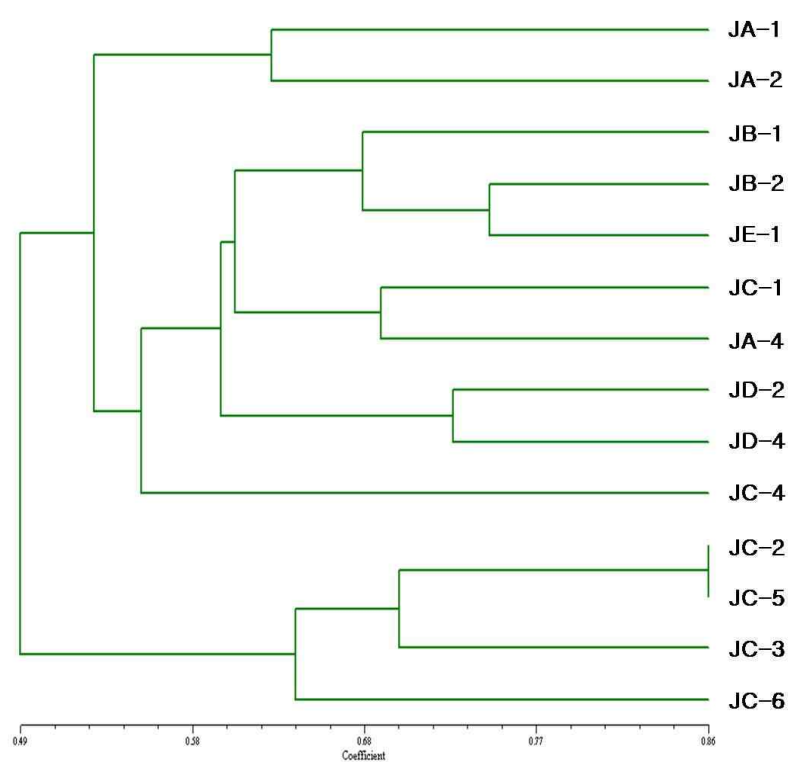

Fig. 2. UPGMA dendrogram of genetic relationships among 14 leaf mustard accessions based on RAPD analysis.

그룹 ㅍㄴ는 JB-1, JC-1, JC-4, JD-2, JA-4, JB-2, JE-1, JD-4; 그룹 III는 JC-2, JC-5, JD-4, JC-6로 그룹 지어졌고, JC-2와 JC-5는 $86 \%$ 의 높은 유사도를 나타내었다(Fig. 2). 그러나 양적 형질 조사와RAPD 분석과의 상관관계는 찾아 볼 수 없었다. 이러한 결과는 몇 개의 양적 형질의 유사도가 RAPD분석 결과와 일치 하는 것을 기대할 수는 없었지만 외부의 환경요인과 관계없이 유전적인 특성을 분류할 수 있는 방법으로는 RAPD분석이 유 용하다는 것을 알았다. 또한, $\mathrm{F}_{1}$ 종자생산에 있어서 잡종강세 현상에 유리한 계통은 유전적으로 거리가 먼 원연인 계통을 이용할수록 유리하다. 본 실험에서는 I 그룹과 III 그룹간의 유전적 거리가 가장 멀리 나타난 결과로 부터 $\mathrm{F}_{1}$ 조합 작성을
위하여 I 그룹과 III 그룹에 속하는 계통을 교배 조합으로 이용 하는 것이 가장 적합하다는 결론을 얻었다.

\section{감사의 글}

본 연구는 농림수산식품부 농림기술개발사업의 연구비 지 원에 의하여 수행되었습니다.

\section{References}

1. Cartea, M. E., P. Soengas, A. Picoaga, and A. Ordais. 2005. Relationships among Brassica napus (L.) germplasm from Spain and Great Britain as determined by RAPD markers. Genetic Resources and Crop Evolution 52, 655-662.

2. Delourme, R., A. Bouchereau, M. Hubert, M. Renard, and B. S. Landry. 1994. Identification of RAPD markers linked to a fertility restorer gene for the Ogura radish cytoplasmic mail sterility of rapeseed (Brassica napus L.). Theor. Appl. Genet. 88, 741-748.

3. Fukuoka, S., K. Hosaka, and O. Kamijima. 1992. Use of random amplified polymorphic DNAs (RAPDs) for identification of rice accessions. Japan J. Genet. 67, 243-252.

4. Han, Z. L., Y. J. Won, J. D. Yea, K. W. Cha, Y. I. Cho, and H. J. Koh. 2001. Relationship between genetic similarity and heterosis of growth characters under cold-water irrigation in Rice. Korean J. Breed 33, 119-125.

5. Jeong, E. J. 2008. A comparative study of food components by species, seasons and parts of Brassica juncea in Yeosu region. M. Thesis, Chonnam National University, Yeosu, Korea.

6. Jo, Y. S., H. S. Cho, I. S. Nou, and K. K. Shim. 2001. Morphological characteristics and classification of staminate Actinidia species. J. Kor. Soc. Hort. Sci. 42, 310-314.

7. Kim, S. K. and B. J. Ahn. 2002. RAPD-mediated determination of genetic relatedness in oriental lilies. Kor. J. Hort. Sci. Technol. 20, 246-251.

8. Lee, J. S. and B. M. Kim. 2005. Analysis of genetic relationship among Arisaema species using RAPD. Kor. J. Hort. Sci. Technol. 23, 459-464.

9. Mackill, D. J. 1995. Classifying Japonica Rice cultivars with RAPD Markers. Crop Sci. 35, 889-894.

10. Murray, M. G. and W. F. Thompson. 1980. Rapid isolation of high molecular weight plant DNA. Nucleic Acids Research 8, 4321-4326.

11. Nei, M. and W. Li. 1979. Mathematical model for studying genetic variation in terms of restrictions endonucleases. Pros. Natl. Acad Sci. USA. 76, 5269-5273.

12. Park, H. J., I. H. Lee, H. T. Kim, S. Y. Yang, and I. S. Nou. 2007. Analysis of genetic similarity of Dolsan leaf mustard based on several horticultural traits and RAPD. Kor. J. Hort. Sci. Technol. 25, 1-6.

13. Park, H. J., I. H. Lee, J. J. Park, S. Y. Yang, and I. S. Nou. 2007. Analysis of characteristics and test of combining ability in leaf mustard allies. Korean J. Plant Res. 20, 298-303. 
14. Qin, Y., H. L. Li, and Y. D. Guo. 2007. High-frequency embryogenesis, regeneration of broccoli (Brassica oleracea var. italica) and analysis of genetic stability by RAPD. Scientia Horticulturae. 111, 203-208.

15. Saghi Maroof, M. A., G. P. Yang, Q. F. Zhang, and K. A. Gravois. 1997. Correlation between molecular marker distance and hybrid performance in U.S. southern ling grain rice. Crop. Sci. 37, 145-150.

16. Williams, J. G. K., A. R. Kubelil, H. J. Livk, J. A. Rafalski, and S. V. Tingey. 1990. DNA polymorphics amplified by arbitrary primer are useful as genetic markers. Nucl. Acids
Res. 18, 6531-3535.

17. Xiao, J., Z. Li, L. P. Yuan, S. R. McCouch, and S. D. Tanksely. 1996. Genetic diversity and its relationship to hybrid performance and heterosis in rice as revealed by PCR-based markers. Theor. Appl. Genet. 92, 637-643.

18. Yu, L. X. and H. T. Nguyen. 1994. Genetic variation detected with RAPD markers among upland and lowland rice cultivars (Oryza sativa L.). Theor. Appl. Genet. 87, 668-672.

19. Zheng, K. L., B. Shen, and H. R. Qian. 1991. DNA polymorphisms generated by arbitrary primed PCR in rice. Rice Genet. Newsl. 8, 134-136.

\section{초록 : RAPD 분석에 의한 여수 돌산갓의 유연관계 분석}

이인호 · 박종인 $\cdot$ 정운섭 ${ }^{1} \cdot$ 정효진 $^{2} \cdot$ 노일섭*

(순천대학교 원예학과, ${ }^{1}$ 여수시농업기술센터 특산품육성과, ${ }^{2}$ 전라남도농업기술원 원예연구소)

RAPD 방법을 이용하여 14 의 돌산갓 품종의 유전적 다형성을 분석하였다. 39개의 random primer를 실험하여 그 중 7개의 다형성을 나타내는 primer를 선발 하였다. 증폭된 PCR 산물은 $0.2 ~ 3.5 \mathrm{~kb}$ 사이에서 재현성 있는 밴드를 나타내었으며, 각 primer에 의해 증폭된 밴드의 수는 2 27개로 다양하였고, 평균 8.7개였다. UPGMA 분 석에 의해 14 개 품종은 3 개의 그룹으로 나뉘었다. 이 결과들로부터 갓의 유전적 다양성 검토 및 $\mathrm{F}_{1}$ 품종 생산을 위한 교배 조합 작성에 RAPD 분석은 유용하다는 것을 나타내었다. 